\title{
Establishment and Empirical Analysis of Evaluation Index System for Basic Public Service Level of Transportation
}

\author{
Jingling Jiang ${ }^{1}$, Luyang Gong ${ }^{2}$ and Yanhong $\mathrm{Li}^{3}$ \\ 1, 2, 3 China Academy of Transportation Sciences, Room 805, No.240, Chaoyang District, Beijing China
}

\begin{abstract}
The establishment of evaluation index system of basic public service level of transportation is of great guiding significance to improving China's comprehensive transportation development, whereas it is lacking in a complete set of practical and standardized evaluation index system for basic public services of transportation. This paper analyzes the connotations and characteristics of basic public services of transportation to determine its scope and content at present and develop the rating index system and index calculation method that cover four aspects of urban public transportation, rural passenger transportation, rural highways and universal postal service of three categories. Through analysis and comparison of the comprehensive evaluation methods of multiple indexes and based on the structural characteristics of the basic public service evaluation indexes of transportation, the paper combines AHP with fuzzy evaluation method to build a quantitative model of multi-index comprehensive evaluation to provide comprehensive evaluation method for basic public service evaluation of transportation. In addition, it also takes Xiji County of Ningxia Hui Autonomous Region as example to evaluate the basic public service level of the transportation, and it can detect through evaluation problems and deficiencies existing in basic public services of its transportation, so as to take corresponding measures for those problems and deficiencies.
\end{abstract}

\section{Introduction}

The 18th National Congress of CPC explicitly put forward that equal access to basic public services should be generally achieved by 2020.As one of the important service industries for protection and improvement of people's livelihood, transportation shall pro mote the close correlation of the equal access to basic public services to the transportation industry. In addition, the current period and the period from now on are vital to fully upgrading the basic public service level of transportation. But the precondition for equal access to basic public services of transportation is that researches shall be conducted on the difference between basic public service levels of transportation in different areas.It requires researches on basic public service items of transportation at first and then the establishment of evaluation index system in which certain indexes and steps shall be taken to provide support and basis for evaluation of basic public service levels of transportation in different areas.

At present, the country is lacking in researches on evaluation indexes and evaluation methods for basic public services of the transportation. When it comes to index system and evaluation model, there is no reference for evaluation of basic public service level of transportation in the country. Development and equalization of basic public services of transportation in different areas cannot be described quantitatively, bringing promotion in equal access to basic public services of transportation certain obstacles. But some researches have been carried out in the country with regard to the evaluation indexes of basic public services. For instance, Li Jian took the second level indexes based on the first level index system established with 6 basic public service items to research the mechanis $m$ that how major indexes influence the supply of basic public services[1]. XuCuimei established the evaluation index system for equal access to basic public services in Hainan and reached the conclusion that equal access to residence is the biggest factor of comprehensive evaluation after analysis through entropy evaluation method[2]. Based on the actual investigation in 198 prefecture-level cities in China, Lin Yangyan et al took basic education, basic medical care and health, environmental protection and infrastructure as four evaluation indexes to figure out the Gini coefficient of the supply of basic public services in the country[3]. Ma Hao et al established the evaluation index system for equal access to public services based on empirical researches on representative provinces and cities of east, central, west regions and gave suggestions for promoting equal access[4]. Wang Xinmin et al established the multi-level evaluation index system for equal access to basic public services, then determined index weight with AHP and adopted the grey correlation comprehensive evaluation model to evaluation the equal access to basic public services in 31 provincial areas throughout the country[5]. In addition, researches conducted with regard to evaluation of basic public 
services provide reference for researches on basic public services of trans portation.

\section{Understanding of basic pbulic service of transportation}

\subsection{Connotation and characteristics of basic public services of transportation}

The State Council issued the Twelfth Five-year Plan for National Basic Public Service System in July 2012 to give the clear definition of basic public services in a formal document for the first time that basic public services refer to the public services that are established on some social common understanding, led and provided by the government and compatible with the economic and social development level, aiming at safeguarding the basic survival and development needs of all citizens. Citizens are entitled to basic public services while the government is liable for providing basic public services. Basic public services refer to the services that the government provides for all citizens mainly for free or public benefit to satisfy the most fundamental need of all citizens and all citizens have equal access to services. Compared to basic public services, non-basic public services refer to high level services the government provides for the society in order to give response to higher level public demand by exercising the public powers or resources in its hands. In addition, the public can voluntarily decide whether or not to enjoy the non-basic public services according to their own conditions and needs [6].

As clothes, food, shelter and travel are the most fundamental needs for survival, the ultimate goal of the transportation industry is to provide the economic society direct travel and transportation services. In the Twelfth Five-year Plan for National Basic Public Service System, the government explicitly pointed out the scope of basic public services, also including public services in transportation in close relation to people's living environment in a broad sense. The scope of basic public services covers the field of transportation, which does not mean that the scope and content of entire transportation service are included in the scope of basic public services. It is just like the nine-year compulsory education in the field of education that is included in the scope of basic public services, but higher education is outside the scope of basic public services. Public services of transportation can also be divided into basic public services and non-basic public services of transportation.

With a reference to the definition of basic public services in the Twelfth Five-year Plan for National Basic Public Service System, the basic public services of transportation refer to the public services led and provided by the government and compatible with the development level and stage of the economic society, aiming at safeguarding the basic travel demand of all citizens. The basic characteristics are as follows: First is being led by the government; second is being compatible with the development stage; third is safeguarding the basic travel demand and fourth is indicating the idea of comprehensive transportation.

\subsection{Scope and content of basic public services of transportation}

According to the Twelfth Five-year Plan for National Basic Public Service System, basic public services of transportation during the period of the "Twelfth Five-year Plan" include providing administrative villages with highways and regular passenger buses, full coverage of public transportation in urban built-up area, making each township have post office and village accessible by postal communication and so on. The content proposed of basic public services of transportation mainly focuses on the field of infrastructure, which relies mainly on the local government's comprehensive planning and overall arrangement based on the local natural, geographical and ecological environment and other actual conditions.

Based on the understanding of basic public services of transportation and strict definition of the development stage where the country's economic society is, basic public services of transportation can be divided into two parts, that is, transportation infrastructure and transportation services. It is known that infrastructure is the basic condition for public travel, and from the viewpoint of transportation infrastructure, it mainly includes the infrastructure in highway, waterway, postal service and other categories that are more popular at present, such as road highway infrastructure system, transport station of transportation and so on. If looking from a pers pective of transportation services, some basic transportation services serving the general public are included in the scope of basic public services, such as public transportation, urban-rural regular bus line and so on in urban public transportation system, providing the general public convenient and low-cost travel services. As a result, the paper suggests that the current basic public service items of transportation shall include urban public transportation, rural passenger transportation, rural highway and universal postal services.

\section{Establishment of evaluation index system for basic public service level of transportation}

\section{Selection principle of evaluation index}

There are a lot of indexes involved in evaluation of basic public services of transportation, but be sure to select the indexes as few as possible for overall evaluation of the development level to reflect the most important and comprehensive information, making each index relatively independent, quantifiable and universal.

(1) Systematicness

Evaluation index system can fully reflect the development of basic public services of transportation as an organic whole. It is required to reflect function of basic public service items of transportation and the 
systematicness and coordination between items and the inside, otherwise the evaluation results are unreliable, which may even misguide the behaviors of the superior management department and the internal management.

(2) Scientificity

The indexes selected should be scientific and reasonable, and can reflect the complete picture and development level of basic public services of transportation truly and objectively. In addition to this, index concept shall be precise and scientific rather than ambiguous, the explanation shall be accurate without different meanings and the data source and calculating range shall be clear and stay the same[7].

(3) Objectivity

Make sure the evaluation indexes are selected in an objective and fair way, data source is reliable and accurate and the evaluation method is scientific.

(4) Operability

When it comes to index selection, be sure to obtain the statistics released by the statistical department on a regular basis as much as possible or obtain through sampling survey and typical survey. Those indexes selected shall be measurable and easy to be quantified.

(5) Comparability

It requires that the data used shall be comparable. The indexes selected shall have the uniform definition and measurement standard in each evaluation object to ensure evaluation and comparis on are conducted on the same basis. For indexes that have unclear concept and cannot be measured, be sure to select no evaluation index as possible[8].

(6) Conciseness

Indexes shall be typical and representative because basic public services of transportation involve many factors and there are a huge number of indexes reflecting the current development. Under the premise of ensuring systematicness, be sure to reflect the most important characteristics with minimum indexes and try to select those representative comprehensive and major indexes as possible.

There are many types of indexes related to basic public services of transportation, but precise quantification does not mean accurate evaluation. For overall evaluation of the development level, be sure to select the indexes as few as possible to reflect the most important and comprehensive in formation, making each index relatively independent, quantifiable and universal. All in all, be sure to adhere to the unity of principles of systematicness, scientificity, objectivity, operability, comparability and conciseness when designing and screening the indexes.Principles of systematicness, scientificity and objectivity have a far-reaching significance for theoretical discussion on the evaluation index system of basic public services of transportation; while principles of operability, comparability and conciseness are conductive to the promotion and application of the index system in actual evaluation.
It is the government's job to provide basic public services. Firstly, the government shall provide basic public services in terms of policy, fund and so on, that is, use supply-side indexes to evaluate the government's supply of basic public services. However, the country has a vast territory with extremely unequal distribution of population and resources, so the government's supply cannot be the only one taken into account [9]-For instance, population density and other factors have an important influence on this. Even though the same government supply, the service level may be different due to different population distribution and density. Therefore, the paper holds that the government's actual ability to provide basic public services needs to be evaluated under the constraint of the existing supply-side indexes, which reflect the basic public service level to which everyone has access, that is, indexes related to ability. Constrained by supply indexes and ability indexes, results shall be taken into account that the basic public service have achieved, such as the proportion of public travel by public transportation, accident rate and so on.

Based on the analysis above, the evaluation index system for basic public services of transportation shall be established from three aspects of supply, ability and result. When evaluating the basic public services of transportation of some area, be sure to establish the index system including the three indexes mentioned above and apply the method of giving different coefficient or weight to comprehensive evaluation.

\subsection{Evaluation index}

There are many factors that affect the basic public service level of transportation. But specific to three aspects of each service item of basic public services of transportation, there are a lot of evaluation indexes involving every aspect of economic and social life. In addition, it seems to be tedious and difficult to evaluate all indexes, so the paper selects the important indexes that are representative and available in data as evaluation indexes.

Based on the content and items of the basic public services of transportation analyzed and combined with the present situation of basic public service level of transportation, the paper follows the principle of operability and other index selection principles to classify the evaluation indexes for basic public services of transportation into 18 indexes, which can be summed up as four aspects, that is, urban public transportation, rural passenger transportation, rural highway and universal postal service.

Evaluation indexes for basic public services of transportation are shown in Table 1, including specific definitions of evaluation indexes and calculating methods.

\subsection{Category of indexes}


Table 1 Evaluation Indexes for Basic Public Services of Transportation

\begin{tabular}{|c|c|c|c|c|}
\hline $\begin{array}{l}\text { First } \\
\text { level } \\
\text { index }\end{array}$ & $\begin{array}{l}\text { Second } \\
\text { level } \\
\text { index }\end{array}$ & Third level index & Index definition & Calculating method \\
\hline \multirow{4}{*}{$\begin{array}{l}\text { Urban } \\
\text { public } \\
\text { transporta } \\
\text { tion }\end{array}$} & Supply & $\begin{array}{l}\text { Operating subsidy } \\
\text { system for public } \\
\text { buses and } \\
\text { trolleybuses and } \\
\text { arrival rate }\end{array}$ & $\begin{array}{l}\text { The ratio of the actual subsidy for } \\
\text { urban public transportation and total } \\
\text { policy subsidy reasonably calculated } \\
\text { during the statistical period. (Unit: \%) }\end{array}$ & $\begin{array}{l}\text { Arrival rate of operating subsidy for public } \\
\text { transportation=Actual subsidy for urban } \\
\text { public transportation/total policy subsidy } \\
\text { reasonably calculated } \times 100 \%\end{array}$ \\
\hline & \multirow[b]{2}{*}{ Ability } & $\begin{array}{l}\text { Public vehicle } \\
\text { population per } \\
10,000 \text { people }\end{array}$ & $\begin{array}{l}\text { Average operating public buses per } \\
10,000 \text { people calculated by urban } \\
\text { population during the statistical } \\
\text { period. (Unit: Standard } \\
\text { vehicle/ } 10,000 \text { people) }\end{array}$ & $\begin{array}{l}\text { Public vehicle population per } 10,000 \\
\text { people=Total public vehicle population / } \\
\text { urban population }\end{array}$ \\
\hline & & $\begin{array}{l}\text { Coverage ratio of } \\
\text { public transport } \\
\text { stations within } \\
500 \mathrm{~m}\end{array}$ & $\begin{array}{l}\text { Ratio of cover area within a radius of } \\
500 \mathrm{~m} \text { of the public transportation } \\
\text { stations within the built-up area of the } \\
\text { central urban area and the area of } \\
\text { built-up area in the central urban area } \\
\text { during the statistical period. (Unit: \%) }\end{array}$ & $\begin{array}{l}\text { Coverage ratio of public transport stations } \\
\text { within } 500 \mathrm{~m}=\text { Cover area within a radius } \\
\text { of } 500 \mathrm{~m} \text { of the public transportation } \\
\text { stations within the built-up area of the } \\
\text { central urban area / the area of built-up area } \\
\text { in the central urban area } \times 100 \%\end{array}$ \\
\hline & Result & $\begin{array}{c}\text { Passenger } \\
\text { satisfaction rate of } \\
\text { public } \\
\text { transportation }\end{array}$ & $\begin{array}{c}\text { Average score of effective } \\
\text { questionnaires about passenger } \\
\text { satisfaction of public transportation } \\
\text { service quality during the statistical } \\
\text { period. (Unit: \%) }\end{array}$ & $\begin{array}{l}\text { Passenger satisfaction rate of public } \\
\text { transportation=Copies of satisfied } \\
\text { questionnaires / total copies of } \\
\text { questionnaires } \times 100 \%\end{array}$ \\
\hline \multirow{5}{*}{$\begin{array}{l}\text { Rural } \\
\text { passenger } \\
\text { transporta } \\
\text { tion }\end{array}$} & Supply & $\begin{array}{l}\text { Support policy } \\
\text { level of rural } \\
\text { passenger } \\
\text { transportation }\end{array}$ & $\begin{array}{c}\text { Support policies for rural passenger } \\
\text { transportation issued by the local } \\
\text { government or industry management } \\
\text { department. }\end{array}$ & $\begin{array}{l}\text { It can be divided into four aspects, subsidy } \\
\text { policy for vehicle purchase, preferential } \\
\text { policy for ticket price, subsidy policy for } \\
\text { policy loss and subsidy policy for station } \\
\text { construction, and relevant policies have } \\
\text { been issued, that is, full score for the item. } \\
\text { In addition, the policy document shall } \\
\text { prevail. }\end{array}$ \\
\hline & \multirow{2}{*}{ Ability } & $\begin{array}{l}\text { Proportion of } \\
\text { incorporated } \\
\text { villages accessible } \\
\text { by passenger cars }\end{array}$ & $\begin{array}{l}\text { Proportion of incorporated villages } \\
\text { accessible by passenger buses of the } \\
\text { total incorporated villages in the } \\
\text { administrative region (Unit: \%). }\end{array}$ & $\begin{array}{l}\text { Proportion of incorporated villages } \\
\text { accessible by passenger cars }=\text { Number of } \\
\text { incorporated villages accessible by } \\
\text { passenger cars / total number of } \\
\text { incorporated villages } \times 100 \%\end{array}$ \\
\hline & & $\begin{array}{l}\text { Proportion of } \\
\text { islands with a } \\
\text { population of more } \\
\text { than } 500 \text { accessible } \\
\text { by regular liners }\end{array}$ & $\begin{array}{l}\text { Proportion of islands with a } \\
\text { permanent resident population of } \\
\text { more than } 500 \text { that are accessible by } \\
\text { regular liners of the total in the } \\
\text { administrative region (Unit: \%). }\end{array}$ & $\begin{array}{c}\text { Proportion of islands with a population of } \\
\text { more than } 500 \text { accessible by regular liners / } \\
\text { number of islands with a population of } \\
\text { more than } 500\end{array}$ \\
\hline & \multirow[b]{2}{*}{ Result } & $\begin{array}{l}\text { Passenger capacity } \\
\text { per capita }\end{array}$ & $\begin{array}{l}\text { Ratio of road and waterway passenger } \\
\text { capacity and the permanent resident } \\
\text { population in the administrative } \\
\text { region (Unit: number of times/per } \\
\text { capita per day). }\end{array}$ & $\begin{array}{c}\text { Passenger capacity per capita }=(\text { Annual } \\
\text { road passenger capacity }+ \text { annual waterway } \\
\text { passenger capacity }) /(\text { permanent resident } \\
\text { population } \times 365)\end{array}$ \\
\hline & & $\begin{array}{l}\text { Death rate of traffic } \\
\text { liability accidents } \\
\text { per } 10,000 \text { vehicles } \\
\text { in rural passenger } \\
\text { transportation }\end{array}$ & $\begin{array}{c}\text { Traffic death toll due to equal and } \\
\text { above liabilities of corresponding } \\
\text { mileage for rural passenger service } \\
\text { vehicles during the statistical period. } \\
\text { (Unit: people/million vehicle } \\
\text { kilometers) }\end{array}$ & $\begin{array}{l}\text { Death rate of traffic liability accidents per } \\
10,000 \text { vehicles in rural passenger } \\
\text { transportation= Traffic death toll of rural } \\
\text { passenger transportation / total op erating } \\
\text { mileage of rural passenger transportation }\end{array}$ \\
\hline $\begin{array}{c}\text { Rural } \\
\text { highway }\end{array}$ & Supply & $\begin{array}{l}\text { Support policy for } \\
\text { rural highways }\end{array}$ & $\begin{array}{l}\text { Fund support policies for rural } \\
\text { highway construction, management } \\
\text { and maintenance and implementation } \\
\text { during the statistical period. }\end{array}$ & $\begin{array}{l}\text { Including proportion of supporting funds } \\
\text { for rural highway construction, } \\
\text { exp enditures for management agencies of } \\
\text { rural highway incorporated in financial } \\
\text { budget and implementation of funds for } \\
\text { maintenance of rural highways. Calculate } \\
\text { the policy score according to the proportion } \\
\text { of supporting funds for construction, and }\end{array}$ \\
\hline
\end{tabular}




\begin{tabular}{|c|c|c|c|c|}
\hline & & & & $\begin{array}{l}\text { calculate the scores of the two policies } \\
\text { according to expenditures for management } \\
\text { agencies of rural highway incorporated in } \\
\text { financial budget and implementation of } \\
\text { funds for maintenance of rural highways }\end{array}$ \\
\hline & Ability & $\begin{array}{c}\text { Rate of } \\
\text { incorp orated } \\
\text { villages provided } \\
\text { with hardened } \\
\text { roads }\end{array}$ & $\begin{array}{l}\text { Proportion of incorporated villages } \\
\text { provided with hardened roads of the } \\
\text { total incorporated villages in the } \\
\text { administrative region (Unit: \%). }\end{array}$ & $\begin{array}{c}\text { Rate of incorporated villages accessible by } \\
\text { highways }=\text { Number of incorporated villages } \\
\text { provided with hardened roads / total } \\
\text { number of incorp orated villages } \times 100 \%\end{array}$ \\
\hline & Result & $\begin{array}{l}\text { Proportion of rural } \\
\text { highways with } \\
\text { medium and above } \\
\text { technical } \\
\text { conditions }\end{array}$ & $\begin{array}{c}\text { Proportion of rural highway mileage } \\
\text { with medium and above technical } \\
\text { conditions of the total rural highway } \\
\text { mileage in the administrative region } \\
\text { (Unit: \%). }\end{array}$ & $\begin{array}{c}\text { Proportion of rural highways with medium } \\
\text { and above technical } \\
\text { conditions }=(\text { High-quality }+ \text { quality }+ \text { medium } \\
\text {-quality rural highway mileage }) / \text { total rural } \\
\text { highway mileage } \times 100 \%\end{array}$ \\
\hline \multirow{4}{*}{$\begin{array}{l}\text { Universal } \\
\text { postal } \\
\text { service }\end{array}$} & Supply & $\begin{array}{l}\text { Support policy for } \\
\text { universal postal } \\
\text { service }\end{array}$ & $\begin{array}{l}\text { Support policies for infrastructure } \\
\text { construction land, capital and so on } \\
\text { and implementation of universal } \\
\text { postal services during the statistical } \\
\text { period }\end{array}$ & $\begin{array}{l}\text { With relevant policies issued, full score for } \\
\text { relevant polices, otherwise no score. }\end{array}$ \\
\hline & \multirow{2}{*}{ Ability } & $\begin{array}{l}\text { Passing rate of } \\
\text { facilities in post } \\
\text { office branches }\end{array}$ & $\begin{array}{c}\text { Ratio of number of postal office } \\
\text { branches in the administrative region } \\
\text { and the number of postal office } \\
\text { branches to be designed according to } \\
\text { the universal postal service standard } \\
\text { (Unit: \%). }\end{array}$ & $\begin{array}{l}\text { Passing rate of facilities in post office } \\
\text { branches }=\text { Number of postal office } \\
\text { branches/ number of postal office branches } \\
\text { to be designed } \times 100 \%\end{array}$ \\
\hline & & $\begin{array}{c}\text { Prop ortion of } \\
\text { incorporated } \\
\text { villages accessible } \\
\text { by postal } \\
\text { communication }\end{array}$ & $\begin{array}{l}\text { Ratio of incorporated villages } \\
\text { accessible by postal communication } \\
\text { and total incorporated villages in the } \\
\text { administrative region (Unit: \%) }\end{array}$ & $\begin{array}{c}\text { Proportion of incorporated villages } \\
\text { accessible by postal } \\
\text { communication=Number of incorporated } \\
\text { villages accessible by postal } \\
\text { communication / number of incorporated } \\
\text { villages * } 100 \%\end{array}$ \\
\hline & Result & $\begin{array}{l}\text { Passing rate of } \\
\text { postal services in } \\
\text { terms of time limit }\end{array}$ & $\begin{array}{l}\text { Passing situation of business hour, } \\
\text { time of checking the postbox } \\
\text { (mailbox) and time limit for the entire } \\
\text { mail according to the requirements in } \\
\text { Universal Postal Services(YZ/T } \\
\text { 0129-2009) during the statistical } \\
\text { period. }\end{array}$ & $\begin{array}{c}\text { Calculate according to the requirements for } \\
\text { business hours in different regions } \\
\text { stipulated in Universal Postal Services } \\
\text { (YZ/T 0129-2009), satisfactory ones can } \\
\text { have the scores. }\end{array}$ \\
\hline
\end{tabular}




\section{Evaluation modeling for basic public service level of transportation}

\subsection{Non-dimensionalization of evaluation index value}

Calculate the evaluation value of each evaluation index involved in basic public services of transportation with the above-mentioned calculating method for each evaluation index and then adopt the calculating method of non-dimensionalization of evaluation index (qualitation and quantification) to non-dimensionalize the indexes.

\subsection{Establishment of evaluation sets}

Divide the evaluation sets into five different levels, that is, "excellent", "good", "average", "poor" and "extremely poor". Then constitute the domain of discourse of evaluation with these evaluation levels and adopt the statistical analysis technique to determine the standard evaluation value of each index based on experts' findings as shown in the table.

Table 2 Table of Basic Public Service Level Grading of Transportation

\begin{tabular}{|l|l|l|l|l|l|}
\hline $\begin{array}{l}\text { Comprehensi } \\
\text { ve evaluation }\end{array}$ & $\begin{array}{l}\text { Excelle } \\
\mathrm{nt}\end{array}$ & $\begin{array}{l}\text { Goo } \\
\mathrm{d}\end{array}$ & $\begin{array}{l}\text { Avera } \\
\text { ge }\end{array}$ & Poor & $\begin{array}{l}\text { Extreme } \\
\text { ly poor }\end{array}$ \\
\hline Score criteria & $100-80$ & $\begin{array}{l}80-6 \\
0\end{array}$ & $60-40$ & $\begin{array}{l}40-2 \\
0\end{array}$ & $20-0$ \\
\hline
\end{tabular}

\subsection{Determine the degree of membership of evaluation indexes and calculate the weight of index values}

Before comprehensive evaluation, be sure to determine the degree of membership of the evaluation index to each level selected in the first place ${ }^{r_{i j t}}$. Measure the frequency $k_{i j t}$ of each index at each evaluation level separately according to the levels provided by experts involved in investigation according to evaluation sets in Table 2, and then figure out the single factor evaluation sets of each index is:

$$
r_{i j}=\left\{\left(k_{i j 1} / n\right),\left(k_{i j 2} / n\right),\left(k_{i j 3} / n\right),\left(k_{i j 4} / n\right),\left(k_{i j 5} / n\right)\right.
$$

, where $\mathrm{n}$ refers to the number of experts involved in the investigation.

Based on experts' findings, the statistical analysis technique shall be adopted to determine the standard evaluation value of each index and AHP to calculate the weight of each sub goal in comprehensive evaluation.

\subsection{Implementation of multi-index fuzzy comprehensiveevaluation}

Firstly is to build the fuzzy relation matrix according to the certain fuzzy membership and then make the final evaluation in the principle of maximum degree of membership.

Assuming the evaluation goal of the evaluation question as B (comprehensive evaluation value), relevant evaluation index () matrix is $\mathrm{Q}=\left\{\mathrm{x}_{1}, \mathrm{x}_{2}, \mathrm{x}_{3}, \cdots, \mathrm{y}_{1}, \mathrm{y}_{2}, \mathrm{y}_{3}, \cdots, \mathrm{z}_{1}, \mathrm{z}_{2}, \mathrm{z}_{3}, \cdots\right\} \quad$ and relevant weight matrix is $\mathrm{W}=\left\{\mathrm{w}_{1}, \mathrm{w}_{2}, \cdots, \mathrm{w}_{\mathrm{n}}\right\}$

$$
B=Q \cdot W^{T}=\sum_{i=1}^{i} x_{i} w_{i}+\sum_{j=1}^{j} y_{j} w_{j}+\sum_{l=1}^{l} z_{l} w_{l}+\sum_{h=1}^{h} v_{h} w_{h}
$$

Where: $x_{i}, y_{j}, z_{1}, v_{h}$ Evaluation value of each constraint;

$W_{n}$ _- Relevant weight of each constraint.

$B$ refers to the final comprehensive evaluation results of basic public service level evaluation of transportation and the evaluation standard is shown in Table 2.

\section{EMPIRICAL ANALYSIS}

The paper takes Xiji County of the Ningxia Hui Autonomous Region (located in the concentrated poverty-stricken area around Liupan Mountain) as the typical example to evaluate the basic public service level of the transportation and the detailed evaluation results are shown in Table 3.

Table 3 Index Scores of Basic Public Service Level Evaluation

\begin{tabular}{|c|c|c|c|}
\hline $\begin{array}{l}\text { Type of } \\
\text { service }\end{array}$ & S.N. & Specific index & Score \\
\hline \multirow{5}{*}{$\begin{array}{l}\text { Urban } \\
\text { public } \\
\text { transpor } \\
\text { tation }\end{array}$} & 1 & $\begin{array}{l}\text { Operating subsidy system for } \\
\text { public buses and trolleybuses } \\
\text { and arrival rate }\end{array}$ & 50 \\
\hline & 2 & $\begin{array}{l}\text { Public vehicle population per } \\
10,000 \text { people }\end{array}$ & 60 \\
\hline & 3 & $\begin{array}{l}\text { Coverage ratio of public } \\
\text { transport stations within } 500 \mathrm{~m}\end{array}$ & 30 \\
\hline & 4 & $\begin{array}{l}\text { Motorized share ratio of public } \\
\text { transportation }\end{array}$ & 20 \\
\hline & 5 & $\begin{array}{l}\text { Passenger satisfaction rate of } \\
\text { public transportation }\end{array}$ & 50 \\
\hline \multirow{5}{*}{$\begin{array}{l}\text { Rural } \\
\text { passeng } \\
\text { er } \\
\text { transpor } \\
\text { tation }\end{array}$} & 6 & $\begin{array}{l}\text { Support policy level of rural } \\
\text { passenger transportation }\end{array}$ & 76 \\
\hline & 7 & $\begin{array}{l}\text { Proportion of incorporated } \\
\text { villages accessible by } \\
\text { passenger cars }\end{array}$ & 62 \\
\hline & 8 & $\begin{array}{l}\text { Proportion of islands with a } \\
\text { population of more than } 500 \\
\text { accessible by regular liners }\end{array}$ & 100 \\
\hline & 9 & Passenger capacity per capita & 50 \\
\hline & 10 & $\begin{array}{l}\text { Death rate of traffic liability } \\
\text { accidents per } 10,000 \text { vehicles } \\
\text { in rural passenger } \\
\text { transportation }\end{array}$ & 85 \\
\hline Rural & 11 & Support policy level of rural & 75 \\
\hline
\end{tabular}
of Transportation in Xiji County 


\begin{tabular}{|c|c|c|c|}
\hline \multirow[t]{4}{*}{ highway } & & highways & \\
\hline & 12 & $\begin{array}{l}\text { Rate of incorporated villages } \\
\text { provided with hardened roads }\end{array}$ & 70 \\
\hline & 13 & $\begin{array}{l}\text { Proportion of rural highways } \\
\text { with medium and above } \\
\text { technical conditions }\end{array}$ & 70 \\
\hline & 14 & $\begin{array}{l}\text { Treatment rate of hidden } \\
\text { dangers in county and } \\
\text { township roads }\end{array}$ & 40 \\
\hline \multirow{4}{*}{$\begin{array}{l}\text { Univers } \\
\text { al postal } \\
\text { service }\end{array}$} & 15 & $\begin{array}{l}\text { Support policy for universal } \\
\text { postal service }\end{array}$ & 82 \\
\hline & 16 & $\begin{array}{l}\text { Passing rate of facilities in post } \\
\text { office branches }\end{array}$ & 76 \\
\hline & 17 & $\begin{array}{l}\text { Proportion of incorporated } \\
\text { villages accessible by postal } \\
\text { communication }\end{array}$ & 100 \\
\hline & 18 & $\begin{array}{l}\text { Passing rate of postal services } \\
\text { in terms of time limit }\end{array}$ & 75 \\
\hline \multicolumn{3}{|l|}{ Total: } & 48 \\
\hline
\end{tabular}

Based on the score of each evaluation index, the total score of basic public service evacuation of transportation in Xiji County is 48 at a medium level, indicating the backward development. It can be seen from Table 3 that different types of basic public services of transportation differ largely in development level, but universal postal service has relatively favorable development level while urban public transportation, rural passenger transportation and rural highway have relatively lower development level. From the scores of specific indexes, it can be observed that Xiji County will increase efforts in operating subsidies for urban public transportation, increase the coverage of public transportation stations and increase the number of public buses and trolleybuses in the future to improve the motorized share ratio of public transportation and passenger satisfaction; raise the rate of incorporated villages accessible by passenger cars and lift the rural passenger capacity; increase efforts in treatment of hidden dangers in county and township roads and raise the conditions for road passage and safety level.

\section{References}

1. Li, J. Research on Evaluation Index System of Basic Public Services [J], Commercial Research, 2011, 409 (05): 48-56.

2. $\mathrm{Xu}, \mathrm{C}$. Research on Evaluation Index System of Equal Access to Basic Public Services-Take Hainan for Example [J], Research and Discussion, 2014(3): 48-52.

3. Lin, Y., Zhang, X., Li, Y. Equal Access to Basic Public Services: Index System, Comprehensive Evaluation and Status Analysis - Based on Empirical Research in 198 Prefecture-level Cities in the Country [J], Fujian Tribune. Humanity and Social Science Edition, 2014(6): 184-192.

4. Ma, H., Zeng, X. Establishment of Evaluation Index System with Equal Access to Basic Public Services in the Country-Based on Empirical Research in Representative Provinces in East, Central and West China [J], Jianghan Tribune, 2011(11): 23-25.

5. Wang, X. Nan, R. Establishment and Application of Evaluation System of Equal Access to Basic Public Services-Based on Empirical Research in 31 Provincial A reas in the Country $[\mathrm{J}]$, Soft Science, 2011, 25(7): 21-26.

6. An, T., Ren, Q. Equal Access to Public Services: Theories, Problems and Strategies [J]. Top HR, 2007 (08): 48-53.

7. Chen, H. Research on China's Basic Public Service System [J]. Scientific Socialism, 2007(3): 98-100.

8. Shao, L., Bai, C. Research on Method for Establishment of Systematic and Comprehensive Evaluation Index System [J]. Journal of Naval University of Engineering, 2008, 20(3): 48-52.

9. Zhao, Y., Li, F. Analysis on Factors with Influence on Regional Differences of Basic Public Services in China [J]. Academic Journal of Shan xi University of Finance and Economics,2009(8):15-22. 